\title{
“They're Different From Who I Am": Making Relevant Identities in the Middle Through Talk-in-Interaction
}

Tim Mossman

This qualitative study builds on earlier research on language and identity by focusing on how Canadian Generation 1.5 university students enact their identities through talk-in-interaction. Drawing on (applied) Conversational Analysis (CA) to analyze critically the production and management of social institutions in talkin-interaction in tandem with Membership Categorization Analysis (MCA) to examine the cultural resources individuals draw on to describe, identify, or make reference to other people and themselves, I undertake a critical discourse analysis (CDA) of data from semistructured interviews with four Generation 1.5 students conducted in a large, public, English-medium university in British Columbia. Rather than approaching the interview as a neutral technology that seeks to discover "truths," I theorize the interviews as meaning-making ventures in themselves, adopting a reflexive orientation that recognizes that data are situated representations co-constructed through interaction with the interviewer. The study reports on how these students, in response to the interactionally occasioned constraints "inhabiting" our talk, produced identities that aligned with select "scholarly representations" from the applied linguistics literature that casts Generation 1.5 students in the middle. The study reveals how identity, power, and social issues are produced and managed in talk-in-interaction and how insights from $M / C A$ might address matters of social justice in educational contexts.

Cette étude qualitative s'appuie sur des recherches antérieures sur la langue et l'identité pour étudier la façon dont les étudiants universitaires de la génération 1,5 (G 1,5) créent leurs identités par la parole-en-interaction. J'ai puisé dans l'analyse conversationnelle appliquée pour analyser la production et la gestion de la parole-en-interaction d'institutions sociales, ainsi que dans l'analyse des catégorisations d'appartenance pour examiner les ressources culturelles auxquelles se réferent les gens pour se décrire, s'identifier ou parler d'eux-mêmes, et pour décrire, identifier ou évoquer les autres. J'ai entrepris une analyse critique du discours à partir de données provenant d'entrevues semi-structurées auprès de quatre étudiants $(G 1,5)$ dans une grande université publique et anglophone en Colombie britannique. Plutôt que d'aborder l'entrevue comme une technologie neutre qui cherche à découvrir des "vérités », j'adopte une orientation introspective reconnaissant que les données sont des représentations qui se construisent par l'interaction avec l'intervieweur et je propose que l'entrevue est une démarche qui donne un sens en soi. L'étude explique comment les étudiants réagissent aux 
contraintes qui « habitent » nos interactions orales pour se construire des identités qui reflètent certaines "représentations académiques » choisies de la littérature en linguistique appliquée portant sur la G 1,5. Cette recherche explique d'une part la production et la gestion de l'identité, du pouvoir et des enjeux sociaux dans la parole-en-interaction et, d'autre part, la façon dont l'analyse des catégorisations d'appartenance pourrait traiter de sujets relatives à la justice sociale dans des contextes pédagogiques.

In many colleges and universities across North America today, the demographic landscape is shifting as cultural globalization and rising immigration lead to increasing numbers of students who defy traditional categories such as mainstream English-speaker, ESL-speaker, or bilingual student. This diverse student population presents university educators and administrators with challenges and opportunities. Over the past decade a new membership category, Generation 1.5, has found its way into mainstream ESL circles and continues to attract the attention of researchers and educators. Much of this research has focused on students in K-12 contexts (Gunderson, 2000, 2007; Talmy, 2005, 2009, 2010) and in ESL, writing or composition programs in United States postsecondary settings (Benesch, 2007, 2008, 2009; Harklau, Losey, \& Siegal, 1999; Lipp, 2011; Roberge, Siegal, \& Harklau, 2009). Other scholars have examined the language socialization experiences of Generation 1.5 students in Canadian contexts (Kim, 2008; Marshall, 2010). This study contributes to this increase in scholarship by focusing on how Canadian Generation 1.5 university students enact their identities through institutional talk. Drawing on (applied) Conversation Analysis (CA) to analyze the production and management of social institutions in talk-in-interaction in tandem with Membership Categorization Analysis (MCA) to examine the cultural resources individuals draw on to describe, identify, or make reference to other people and themselves, I undertake a critical discourse analysis (CDA) of data from semistructured interviews with four Canadian Generation 1.5 students conducted in a large, English-medium university in British Columbia. Although not representative of how multilingual students enact their identities through talk, this study makes a significant contribution to the Generation 1.5 literature by illustrating how the participants and researcher make relevant identity categories and in so doing co-produce a social order as a product of, and design for, the unique circumstances of the institutional interaction. The following question guides this investigation: How do generation 1.5 students construct their sense of being "in the middle" in and through "research interview talk"? 


\section{Literature Review}

\section{Conversation Analysis (CA)}

As a stream of ethnomethodological research, CA developed from the early work of Garfinkel (1967) and Goffman (1955, 1983). For Goffman (1983), conversational interaction was linked to a highly complex interaction order, which opened up investigation of face-to-face interaction by linking rights and obligations to face (i.e., a person's public persona), identity, and macro social institutions. Adding to this work, Garfinkel highlighted the notion of a shared common understanding among participants-what he described as intersubjectivity - which serves as a reservoir of morally obligatory social rules and practices into which participants continually tap to construct shared and specific understandings of their social actions. As a discipline, CA was initiated by Sacks (1992) and Sacks, Schegloff, and Jefferson (1974). In general, two forms of $C A$ research are practiced today: pure $C A$ or basic $C A$ and applied $C A$ or institutional $C A$. The terms pure/applied $C A$ are attributed to ten Have (2007); basic/institutional CA to Heritage (2005). The former is anchored in the early work of Sacks et al., Schegloff being its primary proponent, and examines the institution of talk-in-interaction, that is, how participants understand each other in interaction and the methods they use to do so in situ, such as taking turns, adjacency pairs (pairs of turns found together regularly such as question/answer), preference design (structural bias toward alignment such as affiliation, solidarity), and repair strategies for dealing with interactional trouble. In contrast, institutional $C A$ or applied $C A$ examines the production and management of social institutions in talkin-interaction. Each kind of institutional talk is seen as constituting a "unique fingerprint" (Heritage \& Greatbatch, 1991, p. 95) of interaction involving "specific tasks, identities, constraints on conduct, and relevant procedures that the participants deploy and are orientated to their interactions with one another" (Heritage, 2004, p. 225). Although called conversation analysis, data in both types are not restricted to conversations, but encompass a wide range of naturally occurring interactions such as interviews, speeches, and/or classroom talk. However, it is normally in institutional CA where identity, power, and social issues emerge because these interactions are often characterized by asymmetries of participation, knowhow, and knowledge (Heritage).

\section{Membership Categorization Analysis (MCA)}

Developed by Sacks (1992) in tandem with his early work on CA and embedded in the ethnomethodological tradition of Garfinkel (1967) and Goffman (1983), MCA analyzes how identity categories are produced locally in the here-and-now context of social interaction (and doing everyday life). Conceived of in this way, identities are seen not as fixed like something that exists independently, but rather are said to be enacted through the "display of, or ascription to, membership of some feature-rich category" (Antaki \& 
Widdicombe, 1998, p. 2). In this sense, identity is seen not as something "people passively or latently have.... which then causes feelings and actions" ( $\mathrm{p}$. 2 ), but rather as indexical, occasioned, and procedurally consequential: something that one does and is shaped here and now in talk-in-interaction. Although abandoned by some conversation analysts because of its potential for commonsense analysis, or in Schegloff's (2007) words, analytic promiscuity, there is an increasing trend toward reuniting CA and MCA (below I use the abbreviation M/CA to indicate this union of CA and MCA) as complementary analytic approaches. In particular, the surge in interest in identity in education/social sciences has brought about a renewed interest in M/CA (particularly in the United Kingdom) as a method of analyzing how individuals perform various identities in the routines of everyday interactions (Antaki \& Widdicombe, 1998; Hester \& Eglin, 1997; Hopper \& LeBaron, 1998; Jayyusi, 1984; Lepper, 2000). Increasingly, ethnographers are tapping into M/CA's "critical edge" (Baker, 2000, p. 99) to draw attention to wider ideologies at work in society (Baker; Hester, 1998; Kitzinger, 2000, 2005; Richards, 2006; Stokoe, 2010; Talmy, 2009, 2010;Wilkinson \& Kitzinger, 2008).

\section{Method}

\section{Site of the Study and Participants}

With approval from the ethics committee, the study was conducted between March and May 2010 in a large, public, English-medium university in British Columbia with an enrollment of approximately 32,000 students. The campus is culturally and linguistically diverse, reflecting the changing demographics brought about by increasing immigration and the globalized and globalizing nature of life in the 21st century. Four undergraduate students were recruited for this study: Eva, Sue, Lisa, and Tiffany (pseudonyms). All were Canadians citizens who had immigrated to Canada during adolescence, the central criterion for selection. Eva emigrated with her family from Hong Kong at age 15. At the time of the interview, she was in her second year of a degree in applied sciences. I first met her two weeks before the interview when her academic advisor referred her to me in my role as the ESL/EAL specialist in the Writing Center to help with her English. Sue, a fourth-year economics student at the time of the interview, emigrated with her family from South Korea when she was 14 years old. I first met her a few weeks before the interview when she came to the Writing Center for help with an essay. Lisa and Tiffany were identical twins from Taiwan who came to Canada with their parents at age 14. I first met them at a workshop that I had given. By the time of the interview, they were nearing the end of their studies in psychology and business.

\section{Data Collection and Analytic Framework}

Data were collected from semistructured interviews with the four participants. I conducted the interviews my office in the Writing Center. I interviewed Eva 
and Sue individually once for approximately 30 minutes each, whereas the interview with the twins, whom I interviewed together, lasted approximately an hour. Rather than approaching the interview as a neutral technology that seeks to discover truths, I theorized the interviews as meaning-making ventures in themselves, adopting a reflexive orientation that recognizes that data are situated representations co-constructed through interaction with the interviewer (Holstein \& Gubrium, 2004). During the interviews, I showed the participants a list of select quotations (what I term scholarly representations), which I had collected from the applied linguistics literature from 1988-2009, that describe/define Generation 1.5 students. I compiled these quotations from refereed research articles, chapters from edited books, conference presentations, and doctoral dissertations. I asked the participants how they felt about the term Generation 1.5 and whether they agreed or disagreed with the scholarly representations. I digitally recorded the interviews once with a Live Scribe smart pen. Before analysis, I transcribed the data using symbols derived from those developed by Jefferson (Wooffitt, 2001; see Appendix A). Because no utterance or non-speech sound (e.g., laughter) is considered insignificant in CA, the transcription attempts to capture the sound of the talk as it was originally spoken, drawing attention to timing, sequence, emphasis, pauses, and non-speech sounds. I conducted the analysis by linking the critical agenda of CDA - how social power, abuse, dominance, and inequality are enacted, reproduced, and resisted by text and talk in social and political contexts (Van Dijk, 2001) - with the aims of (applied) CA and M/CA. Given "pure" CA's insistence on approaching data with a "clean gaze" (Stokoe \& Smithson, 2001, p. 6) and CDA's agenda of making its critical framework a priori (Van Dijk), adopting M/CA to undertake a critical discourse analysis of talk could be construed as incompatible. However, rather than doing pure M/CA in the Schegloffian (2007) tradition with its agenda of "unmotivated looking," I use M/CA to shed light on how identity, power, and social issues are produced and managed in the research interview and how insights from $\mathrm{M} / \mathrm{CA}$ might address matters of social justice in educational contexts.

\section{Reflexivity}

Who I am, how I constructed the participants, and how they may have constructed me are highly relevant to this study. I am a white male, Englishspeaking Canadian. I am both a university researcher and university employee. The participants may have oriented to me as an authority and expert who might be able to help them, which may have relevance for how they performed for me. I constructed the participants as multilingual learners with diverse cultural backgrounds and rich linguistic repertoires. However, realizing that struggles involving language are seldom mere linguistic issues, but rather intersect with racism, discrimination, power, and exclusion, which are often economically and politically motivated (Blackledge, 2005; Bourdieu, 
1991; Han, 2009, 2011; Heller \& Martin-Jones, 2001), I also constructed the participants as individuals who may have been perceived as non-legitimate speakers of English, and as a result may have experienced exclusion from social domains where competence in the "standard" "legitimate" language is required (Bourdieu).

\section{Data Analysis and Findings}

"My home country just pull me back there."

Eva, Hong Kong

Before receiving the above reply, I had asked Eva what she thought Generation 1.5 meant (she had not heard of the term before). She replied: "Um::: (2) HA::LF Chin::ese ha:lf (.5) Canadian culture? > I mean like< half my (.5) h:ome country half here (1.5) I guess." In lines 01-02, I invoke my situated identity as a researcher (Zimmerman, 1998). Eva, in her situated identity as student/interviewee, answers my question. Designed in CA terminology to prefer a yes response, my next question (line 05) achieves its intended aim as Eva replies with the latched utterance) "=Ya, what I feel is true " (line 06) followed by a brief account (lines 8-12). Here Eva and I are jointly talking about identity. I then ask whether she feels "being in the middle, in between" (line 10) is a "bad place" (line 14) or a "good place" (line 16) to be. By designing my question in this way-stressing the word bad and uttering it firstI (potentially) alter how Eva interprets and responds to my question. Eva replies that she "didn't feel bad" about being in the middle and seems simply to accept what for her is a fateful consequence of being a Generation 1.5: "ya I'm in the middle, (well) how can I do:? >" (line 18-19).

Extract 1 (R=researcher, E=Eva)

01. R: How do you feel when you read (.5) these descriptions of generation 02. 1.5 students?

03. E: Oh (.) as I read one ${ }^{1}$ and four ${ }^{2} \downarrow$ (.) I think like four is like (.) so:: true.

$04 . \quad(.5)$

05. R: Is that right? =

06. $\mathrm{E}:=\mathrm{Ya}$, what I feel is true $\downarrow$

07. (1)

08. E: > because like < (.) it's:: (1.5) it's like (.) really < dif::ferent. >

$09 . \quad(.5)$

10. E: but in my situation it's like kind of really in the middle, in-between.

11. (2)

12. E: I really agree that.

13. (.5)

14. R: Do you think that's a (.5) bad place to be $\uparrow$

$15 . \quad(.5)$

16. R: or a good place[to be? 
17. E:

[Well (.5) > in my opinion < I didn't feel bad about

18. this, but (.) I just feel that (.) it's like (1.5) ya I'm in the middle,

19. (well) how can I do:? > Like because $\mathrm{I}<(.5)$ it's hard for me to

20. mo:ve it to (.5) change all the perspectives to Canada,[but

21. R:

[Um hmm

22. E: I also like kind of (.5) I should be moving on, right? so in: my::

23. perspective $>$ I didn't feel bad $<$ about the such and such $=$

24. R: =.hh What do you mean I should be moving on $\downarrow$

25. E: Like $>$ because like $<$ I already::: (.) in my old world like $>$ because

26. like $<$ I choosing to move to Canada (.) then I should be (1) um::

27. (.5) more participate in here (.5) and then more enjoy my life here

28. (.5) but ahh: in certain way that sometimes I didn't (.5) feel that I

29. wa::nt to $\uparrow()>$. like just kind of $<$ my: (.5) h::ome country just (um)

30. pull me back th [ere=

31. R: $[\mathrm{Hmm}=$

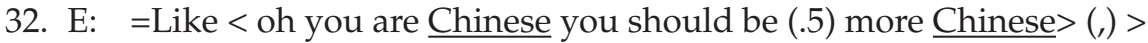

33. you know $<$ in Chinese $>$ and then like because like $<(1)<$ most

34. your friends is in Hong Kong:: $>$ (.) and then $<$ most your friends in

35. your home country $>$ (.) like they are doing the same things

36. >different from you, right? $<$ (.) but you also have a bonding with

37. them=communicate with them, so you can't be like so:: outdated

38. from (.) your home country.

39. R: $\mathrm{Hmm}=$

40. $\mathrm{E}:=>$ so like $<$.hh (.) you like $>$ so that's why I like sometimes I also

41. like< mostly read the Chin:ese newspaper from my: (.) home:

42. country $\uparrow$

43. (.5)

44. R: Umm hmm=

45. $\mathrm{E}:=$ but $(. \mathrm{hh})>$ on the other way $<$ (.) like (.) people that here $>$ should

46. think that like $<$ Oh you guys should be moving on [(.)

47. R:

[Umhmm

48. E: like you should be (.5) in Canada now:: you should be:: like: (1)

49. enjoy the environment here.

50. (1.5)

51. E: like this is what I think.

In line 20, Eva acknowledges the difficulty of "mov[ing]" and adopting a Canadian "perspective[s]," but adds "I should be moving on, right?" (line 22). In response to my question in line 24, Eva builds an account with embedded narratives in which she makes relevant an identity in the middle that is shaped by, and oriented to, the interactional context of talking about Oudenhoven's (2006) quote introduced in lines 01-02. In lines 25-30, she makes relevant her Canadian immigrant identity and what she feels are obli- 
gations and expectations, or in M/CA terminology, "Category-Bound Activities" (CBAs), associated with this Membership Category (MC): "more participate in here (.5) and then more enjoy my life here" (lines 27-28). She follows this by stating that this is not easy: "sometimes I didn't (.5) feel that I wa::nt to " (lines 28-29). Here Eva does identify somewhere in the middle between Canada and Hong Kong: "my h.::ome country" just (um) pull me back th[ere" (lines 29-30). With no uptake from me, Eva extends her turn, keys a shift in footing (Goffman, 2001) initiated by her use of "oh" (Schiffrin, 1987), and animates a narrative in which an (unnamed) figure urges her to "be more Chinese $>$ (.) $>$ you know $<$ in Chinese $>$ " (line 32). Her use of the extreme point "most" (line 34), what Pomerantz (1986) called an "extreme case formulation," provides the figure she animates with just cause why she should "be (.5) more Chinese" (line 32) and not "be like so:: outdated from (.) your home country" (lines 37-38). Eva then describes what she feels is an appropriate CBA for a Chinese immigrant: "so that's why I like sometimes I also like< mostly read the Chin:ese newspaper from my: (.) home: country " (lines 40-41). In line 45, Eva keys another change in footing; her production format (Goffman, 2001) shifts as she animates another unnamed figure(s) "people that here" who "chastise" her for "doing being" too Chinese and not "doing being" Canadian enough: "Oh you guys should be moving on" (line 46). Here she portrays herself as relaying this unnamed figure's expectations of Canadian immigrants like her: "you should be (.5) in Canada now:: you should be:: like: (1) enjoy the environment here" (lines 48-49). Eva's recruitment of the phrase "you guys" (line 46) invokes her membership in the Generation 1.5 group.

\section{"They're different from who I am." Sue, South Korea}

Sue was already familiar with the term Generation 1.5. She told me that it was a popular term in the Korean community: "It's like everybody would know if you say il cheom ose" (literally the " 1.5 generation"). When I asked her what the term meant to her, she replied, "like children who came here after they were born in their own child country. So, not quite Canadian, not quite Korean ... in the middle." Extract 2 begins immediately after reading Rumbaut and Ima's (1988) quote. In line 01, I ask Sue how she feels about this representation of Generation 1.5 students and she aligns herself with it even before I finish asking my question. Her laughter (line 03) works as an "attuning device" (Silverman, 1998, p. 117) to prepare me to hear her story. On a conversational level, my clarification question (line 04) is evidence that I have indeed tuned in and want to hear her story. Yet on another level, it reveals the "institutionality" of our talk because my question (as in Extract 1, line 05 ) is designed to prefer a yes response. Thus I "take and retain the initiative" (Heritage, 2004, p. 236) in how the topic takes shape. Sue's latched reply in 
line 05 ("=Ya, exactly what I'm feeling") is evidence that this is indeed how she has treated my question. By extremitizing her claim ("exactly"), Sue's utterance becomes potentially accountable. With no uptake from me (line 06), Sue orients to this need to provide an account and does so by recruiting two resources, her lack of English-speaking friends and her surplus of Korean-speaking friends. Her sigh (line 08), which prefaces her statement that " $98 \%$ of my friends are " $h$ Korean " (1) Generation 1.5. $\downarrow$," seems to indicate that Sue is disappointed/frustrated that she does not have more English-speaking friends.

Extract 2 (R=Researcher; $\mathrm{S}=$ Sue)

01. R: How do you feel when you (.5) wh[en you read that?

02. S: [That's exactly what I feel

03. actually=hehheh.

04. R: You feel that way?=

05. S: $=$ Ya, exactly what I'm feeling=umm

06. (1)

07. S: ya that's how I felt. .hh cuz:: (.5) I don't have (.) a lot of English (.)

08. English speaking (.5) friends (.5) like (.5).hh ((sighs)) $98 \%$ of my

09. friends are (1).h[Korean.

10. R: $\quad[\mathrm{Hmm}$ :

11. (1)

12. S: Generation 1.5. $\downarrow$

13. $\mathrm{R}:{ }^{\circ} \mathrm{Wow}^{\circ}=$

14. S: $=$ Umhmm.

15. (1)

16. S: and:::

17. R: and they're all Korean generation 1.5. $\downarrow$

18. S: Yes.

19. (2)

20. S: So that's why (.5).hh even though I'm living in (.) Canada (1.5) I'm still, 21. (1)

22. S: my life's always in the Korean society (.5) >except for school $<\downarrow$ (.5) or

23. $\underline{\text { work } \downarrow}$

24. (1.5)

25. S: and then,

26. (3)

27. S: Um, I don't know=if I meet other (.5) cuz I've been here since (.5) like

28. $\quad$ since grade $7=\mathrm{I}^{\prime} \mathrm{ve}$ had a lot of (.5).hh $>$ friends from different countries

29. as well $\uparrow<$

30. R: $\quad{ }^{\circ}$ Right $^{\circ}$

31. S: [but I don't feel like (.) I fit into their (2) group [(.5) ${ }^{\circ}$ as well ${ }^{\circ}$.

32. R: Umhmm. 
33.

(1)

34. S: but I do fit in with this Korean (.) people(.5) Korean friends (.) friends

35. $().[=>$ because they're

36. R: [So why

37. S: also<generation $1.5=$

38. R: =Ya, so why don't you, you say you don't fit into the other (.5) why is 39. that=is that (.5) because of (.5) what (.) language:::or (.5) [cul[ture?

40. S:

[Language:(.5) I

41. think (.5) like (.5) < the (.5) > the main reason $<$ I think (.). hh $>$ o because I

42. don't really understa::nd ${ }^{\circ}<$ some of the sla:ngs they use: (.) like(.5)

43. h.you know how they (.) joke around and stuff (.5) I'm=and I'm always

44. (.) umm I don't [understand (.5)

45. R: $\quad[\mathrm{Oh}::: \mathrm{OK}$.

46. S: $\quad[\mathrm{Ya}=$ so I'm always (.5) out of the (.) communication.

47. R: Ya: so, you must feel (.) kind of uncomfortable [(.5)

48. $S$ :

49 R: when that happens=

[Umhmm.

50. S: =ya, so:: (1) that's when I started to be: more like (.5) fitting into Korean

51. society.

52. R: [Ya::

53. S: [but (.5) the reason why I can fit into Korean society is because (.5) they

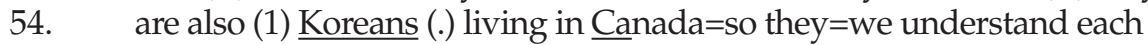

55. other,[right?

56. R: [sure.

57. S: [but,

58. R: [similar exp[eriences.

59. S:

60.

[Umhmm.

61. S: but then (.) when I go back to Korea(.5)

62. R: Ya,

63. S: >the Korean Koreans.<

64. (1)

65. S: the Koreans who live in Korea=hehheh

66. R: The Korean Koreans $\downarrow$

67. S: Yes (.5) Yes, exactly (.) they're different (.) from $(.5)^{\circ}$ who I $a^{\circ}=$

68. R: =Of course.

69. S: Umhmm.

70. $\quad(1)$

71. S: So: (.) that's the difference.

Further evidence of our "interactional asymmetries" (Heritage, 2004, p. 236 ) is revealed in how I respond to Sue's statement that " $98 \%$ of my friends are (1).h[Korean." Both my softly spoken interjection (line 13) 
and my subsequent tag question/statement (line 17) are designed to (i.e., astonishment/falling intonation/tag question) elicit a yes response. That Sue treats the design of my interjection and question in this way, responding immediately in line 14 with the latched utterance ("=Umhmm.") and "Yes" in line 18 illustrates how "the institutional interview," as a type of technology, creates its products and outcomes by a certain kind of subject (de)formation (Foucault, 2003). These interactionally occasioned constraints serve to initialize Sue's second account in lines 20-23. This account suggests that her membership in the Korean-Canadian community comes at a cost: Sue only does (has opportunities to do?) an "English-speaking/Canadian" identity at "school< (.5) or work. $\downarrow$ " (lines 22-23), a situation over which she seems to have no control. Her tone of voice and demeanor suggest that this is something she regrets/is frustrated about but feels helpless to change.

Sue keys a change in footing in line 27 by offering the mitigated utterance "Um, I don't know ..." Her insertion of "I don't know" may be Sue's way of playing down her stake or interest in her earlier account (Potter, 1996). By recruiting two further resources, her length of stay in Canada and her prior network of friends (lines 27-29), Sue produces a local identity that displays (for me) her distinction from newly-arrived immigrants. However, by quickly adding "I don't feel like (.) I fit into their (2) group [(.5) 'as well" (line 31), Sue draws on the relational concept their group as a resource to make her Korean Generation 1.5 membership relevant. Thus she "does being" an identity as a Korean, and then more precisely as a Generation 1.5: "but I do fit in with this Korean (.) people (.5) Korean friends ... > because they're ... also $<$ generation 1.5." (lines 34-37). In lines 38-39, I ask Sue why she finds it hard to fit into their group, offering the prompts language or culture. By phrasing my question in this manner, I limit "what will be "treated as [an] allowable contribution" (Heritage, 2004, p. 225), (potentially) altering how she interprets my question and constructing her as having been perceived as an non-legitimate speaker of English by members of this in group. Sue responds to these constraints by taking up the first of my prompts, "Language: (.5) I think" (lines 40-41), confirming my construction of her and illustrating the power inhabiting the design of my question. This leads to Sue's third account (lines 41-46) through a small story (Bamberg \& Georgakopoulou, 2008) in which she attributes her lack of knowledge of "sla:ngs they use" and their jok[ing] around and stuff "as "the main reason" why she feels excluded. Through her use of the pronouns their (line 31) and they (42 \& 43), Sue makes relevant a "local native English speaker" MC and the CBAs that for her, "authenticate" (Bucholtz \& Hall, 2004) membership in this group: knowledge/competence in local slang and jokes. By stating, "so I'm always (.5) out of the (.) communication" (lines 46), Sue constructs an identity interactionally that aligns with the quote (Rumbaut \& Ima, 1988) that she has just read, that is, an identity that is marginal to her new world[s]. 
In response to my sympathetic aside in line 47 , which is again designed to prefer a yes response, Sue agrees with me (line 48) even before I complete my question. My question initiates her fourth account (lines 49-54), in which she gives two reasons why she "started to be: more like (.5) fitting into Korean society" (lines 50-51): difficulties understanding "native speakers" (line 42) and a closeness she feels with her Generation 1.5 friends: "they are also

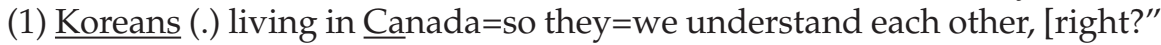
(lines 53-55). Her tag question "right?" serves as an interactional invitation for me (as interviewer and interlocutor) to align with her, which I do (line 56). Her use of the pronoun we clearly speaks her membership as a Generation 1.5 into being. In line 61, Sue's utterance "but then" keys a change in footing and serves to frame the last of her narratives. In line 63, Sue invokes the denotative self-other distinction" $>$ the Korean Koreans.<," which becomes relevant for her when she goes back to Korea. Sue does not topicalize "Korean Koreans" alone, but we co-construct this concept together. This is accomplished by Sue first orientating to my lack of uptake (line 64) as requiring her to provide a definition for me, which she does: "the Koreans who live in Korea=hehehe" (line 65). My response (line 66) then redefines/reconfirms her construction and leads to her enacting an identity that is not "Korean Korean[s]": they're different (.) from (.5) ' who I am ${ }^{\circ \prime \prime}$ (line 67).

\section{"We're neither nor, we're sort of like the stuck in-between." \\ Lisa and Tiffany, Taiwan}

Extract 3 (R=Researcher; T=Tiffany; L=Lisa) occurs at 10:47 (total 107:15 in length) of the interview with Lisa and Tiffany just before my introduction of the "scholarly representations." Tiffany had read about the term Generation 1.5 in a sociology course that she had taken at a community college. I begin by asking a question and introduce the term Generation 1.5 (line 01). Tiffany immediately answers (line 03), making relevant a dual national identity: "Like we're half: (.5) Canadian, he[he half umm: (.) Taiwanese." In answering my question, she simultaneously creates the context for Lisa's utterance in line 05-an upgrade that indexes an identity occupied by non "normals" (Goffman, 1963): "We don't belong (.5) to [the norm."

Extract 3 (R=Researcher; T=Tiffany; L=Lisa)
01. R: What does that mean (.5) to you guys (.5) generation 1.5?
02. (.5)
03. T: Like we're half:(.5) Canadian, he[he half umm: (.) Taiwanese.
04. L:
05. we don't belong (.5)to [the norm
06. T: [to any other group=
07. L: =ya we're neither nor, we're sort of like the (.) stuck in- between.
08. R: You feel that way? 
09. L: Ya.

10. R: Like you're stuck in between $\downarrow$

11. T: $\underline{\text { Ya } \uparrow}$ because we (.) don't belong to the: (.5)

12. L: Mainstream $=$

13. $\mathrm{T}:=$ mainstream (.) like the all Canadian (.) society=but we don't

14. belong to the (.5) all Asian, you know=

15. L: =like fobby (. ) people, he[hheh.

16. T: [hehheh

17. R: The what?

18. T: FO[B.

19. L: [fobby people, hehehe.

20. R: >The what people?<

21. T: FO:B.

22. (.5)

23. R: <What's that. $>$

24. L: Fresh off the boat. That's[a

25. $\mathrm{T}$ :

26. He[hheh

$[\mathrm{FO}: \mathrm{B} \downarrow$

27. [hehheh=

$28 . \quad(1.2)$

29. R: So, what's a FO:B? = fobby people you said.

30. L: =>Like if people call you a FOB (.) that means you just got to Canada $<$

31. (.) you just got here (.) and you're $=>($ ) $>$ it's not very nice but people

32. say it all the time $=$ I don't have any $<$

$33 . \quad(.5)$

34. R: So (.) so a FOB is::?

35. (.5)

36. R: what's a [FOB?

37. T: $\quad$ [Fr[esh off the boat.

38. L: [Fresh off the boat=

39. R: So so[me

40. T: $\quad$ [people who just (.) came here (.5) an[d don't(.)

41. L:

42. =who don't speak good English. [doesn't speak really=

$43 . \quad(1)$

44. R: $\mathrm{O}(\mathrm{h}) \mathrm{K}$ :

45. T: who speaks with a strong accent (.) and who doesn't know (.) things 46. around here, [heheheh.

47 L: [hehehe

Following this, Tiffany's overlapping utterance (a further upgrade) in line 06 ("any other group") serves to legitimize the claim that her sister made by her use of the extreme point any (Pomerantz, 1986). In line 07, Lisa aligns herself 
vis-à-vis her sister's prior utterance as indicated by her latched "=ya", further extremitizing their claim: "we're neither nor" (lines 07), in effect upgrading their identity to that of perpetual foreigner: "the (.) stuck in-between." Their back and forth talk, a distinctive feature of their interaction with me and with each other throughout the interview, is evident in their overlapping utterances (lines 03-04; 05-06; 26-27; 39-40; 40-41; 46-47) and the completion/renewal of each other's utterances (lines 12-13; 15-16). This may be because as identical twins they have learned how to read each other. From a CA analytic perspective, it speaks to their sophisticated level of sensitivity to context and "how [their] mutual understandings are created through a sequential architecture of intersubjectivity" (Heritage, 2005, p. 105).

As in my interaction with Eva and Sue, my questions in lines 8 and 10 prefer a yes response, revealing the power I have to steer the discussion, (re)enact my researcher's identity, and co-construct their sense of being stuck in the middle. Both Lisa and Tiffany answer my questions with "Ya" (lines 9 and 11), which leads directly to another account: "because we (.) don't belong to the: (.5)." Lisa treats Tiffany's brief .5-second pause at the end of line 11 as an opportunity to take a turn. She completes her sister's utterance for her, and in so doing mentions a "[M]ainstream" identity (line 12), to which Lisa adds an upgrade via her use of a latched utterance and another extreme case formulation: "like the all Canadian (.) society." However, in lines (14-16) Tiffany and her sister coproduce a denotative self-other distinction: "but we don't belong to the (.5) all Asian, you know=." Lisa follows this with a derogatory upgrade, which is designed specifically for me: "=like fobby (.) people." Their overlapping laughter (lines 15-16, 46-47) and my embedded laughter (line 44) suggests affiliation and acts as a way to remedy a possible interactional impropriety (i.e., by occasioning this derogatory term) (Jefferson, Sacks, \& Schegloff, 1987). In line 15, Lisa invokes the term $F O B$, which for her and her sister serves as a relational concept of self. According to Pyke and Dang (2003), FOB (Fresh Off the Boat) is a "symbolic device[s] used to create meaning, mark and maintain internal social boundaries, and control social behavior among coethnic peers" (p. 155). My question in line 17 keys in a shift in the interaction as the term FOB becomes topicalized. It is important to note here that Tiffany and Lisa do not topicalize $F O B$, but that we do this together, sequentially for the remainder of the interview (lines 15-37). Yet it is my turn design that prevails (lines 17; 20; 23; 29 ; 34 ) in determining when FOB is satisfactorily defined. Through the sequential organization of our talk, Lisa, Tiffany and I co-construct an identity in the middle somewhere between "fobby (. ) people" (line 15) and the "=main[stream (.) like the all Canadian (.) society" (line 13).

\section{Results and Discussion}

All four participants made relevant identities in the middle. Eva invoked an identity that was pushed and pulled between two worlds. Although she felt 
the need to move on, she seemed to have no control over this and kept getting "pull[ed]...back th[ere" (line 30). In this way, she did an identity in the middle in terms of her not being there and siting herself somewhere between there and here. Eva's lack of agency is significant, for this may speak to the hardships that she and other adolescent immigrants face as visible minorities who must adapt to life and school in North America while negotiating complex, multiple, shifting, and competing identities (Benesch, 2008, 2009; Talmy, 2010).

Sue occasioned her in-betweenness by producing four accounts in which she recruited several relational concepts of identity: newcomer, ("cuz I've been here since (.5) like since grade 7" [lines 27-28]), local native-English speaker ([but I don't feel like (.) I fit into their (2) group [(.5) ${ }^{\circ}$ as well ${ }^{\circ}[$ line 31] ], and Korean-Korean ("they're different (.) from (.5) ${ }^{\circ}$ who I am ${ }^{\circ}=$ " [line 67]) which served to distinguish her from these groups and authenticate (Bucholtz \& Hall, 2004) her membership as a Canadian Generation 1.5. A significant finding in terms of how identity, power, and social issues were produced and managed in our talk was Sue's making relevant an agentless Korean Generation 1.5 identity: few English-speaking friends (line 07) surrounded by Generation 1.5 friends who are also Korean (line 09; 22; 34), few opportunities to live like a Canadian outside her Korean community (">except for school $<\downarrow$ (.5) or work $\downarrow$ " (lines 22-23), unable to fit into their group (line 31), unable to understand their "sla:ngs" and "joke[s]" (lines 42-43) and "always out of the communication" (line 46). However, Sue seemed to exercise her agency and resist these interactionally occasioned constraints by constructing an agentive "credible or genuine identity" (Bucholtz \& Hall, p. 385) as a Canadian-Korean. Her invocation of the term Korean-Korean (and our subsequent co constructed topicalization of it) may suggest that Sue feels that she has more cultural/linguistic capital (Bourdieu, 1991) as a Generation 1.5 Canadian Korean when she is in Korea than when she is in Canada.

Lisa and Tiffany made relevant extreme identities in the middle in and through their interaction with me. One way they accomplished this was through "extreme case formulations"—any, all, neither nor. This suggests that social and institutional orders as they are produced and managed in and through the "temporary artifact[s]" (Harklau, 2000, p. 37) Generation 1.5 is marked by (as they understand it) unequal relations of power and restricted access to Canadian linguistic and cultural resources. For as Heritage (2004) states, "institutional realities also exist in and as documents, buildings, legal arrangements, and so on" (p. 223). A second way that Lisa and Tiffany did identities in the middle was through their co-produced, back-and-forth, tagteam-like intersubjective ascription to the membership category Generation 1.5. This was accomplished by their making relevant a series of identities, each an upgrade of the other-half, non-normal, Other, neither nor, and the stuck in between. Our co-constructed topicalization of the term FOB seemed to (re)affirm Lisa's and Tiffany's identities as non-FOB, and by default occupy 
a higher ranking in the social hierarchy than that of those (Asians) who "just got to Canada $<$ (.) you just got here (.), "who speaks with a strong accent (.) and who doesn't know (.) things around here" (lines 45-46). Another significant finding was that the interview itself allowed Lisa and Tiffany to display their interactional proficiency in English (e.g., overlapping talk, lack of gaps or pauses between our turns, no need for me to clarify and repeat my questions), and distinguish themselves linguistically and culturally from FOBs. This suggests that grammarians such as Chomsky (1965) offer us an incomplete theory of language competence as they "sidestep[s] the question of the economic and social conditions of the acquisition of the legitimate competence and of the constitution of the market in which this definition of the legitimate and the illegitimate is established and imposed" (Bourdieu, 1991, p. 44).

\section{Conclusion}

My aim in conducting this study was twofold: (a) to shed light on how identity, power, and social issues are produced and managed in talk-in-interaction, in particular, in and through "research interview talk"; and (b) to examine how matters of social justice in educational contexts might be addressed. In the researcher/interviewee interactional context of referencing a snapshot of scholarly representations from the applied linguistics literature that cast Generation 1.5 students in the middle, the participants and I co-constructed a "unique fingerprint" (Heritage \& Greatbatch, 1991, p. 95) of meaning, knowledge, and social practices. The finding that all participants sited themselves in the middle is best understood as a "dynamically created thing" (Heritage, 2005 , p. 105) designed for and of their interaction with me. I sought to give voice to the participants (albeit a discursively constructed and situationally dependent voice) and be critical of how scholars have constructed their histories for them instead of with them. However, as I began to analyze the data and look more closely at my role in the co-construction of our talk, my power and privilege as an institutional authority began to emerge. This was evident in our asymmetries of participation, knowhow, and knowledge (Heritage, 2004): introducing my snapshot of scholarly representations; invoking my situated identity as a researcher; designing my questions to prefer yes responses; taking and retaining the initiative; shaping the sequence of our talk; co-topicalizing concepts; and altering/limiting student responses. For those of us (an invoked MC!) with a social justice agenda who conduct interviews as their "windows on the world" (Gubrium \& Holstein, 2002; Hyman et al., 1975) to gain insights into the social worlds of their participants, I respectfully offer a caveat: When we speak from our institutionally legitimized positions of power armed with our "quasi-scientific idiom" (Mehan, 2001, p. 361), we may inadvertently construct the identities of the participants whom we study based on assumptions derived from our scholarly privilege, unintentionally projecting false images onto them. When such discourses enter into circula- 
tion via scholarly literature, they construct a particular authorized and legitimate version of reality. As scholars, we must be cautious of such "regimes of truth" that draw on "conventions ... [which] embody ideological assumptions which come to be taken as mere 'common sense,' and which contribute to sustaining existing power relations" (Fairclough, 1995, p. 77). If we are committed to social justice and resisting and challenging oppression in all its forms, we must adopt "'critical readings' of how power operates and how it transforms and reforms, social relations, through racial categories and consciousness" (Threadgold, 2001, p. 4). In order to address this issue of power between the researcher and researched, I employed M/CA as a means to understand and problematize in the context of interview talk-in-interaction the concept of in-betweenness in educational discourses around the term Generation 1.5.

\section{The Author}

Tim Mossman is currently a doctoral student in the Languages, Cultures, and Literacies program in the Faculty of Education at Simon Fraser University. His professional interests include critical discourse analysis and Generation 1.5. He currently works as the English-as-an-Additional-Language (EAL) services coordinator in the Student Learning Commons at Simon Fraser University.

\section{Notes}

1 “They are in many ways marginal to both the new and old worlds, for they straddle both but are in a profound sense fully part of neither. They occupy the interstices of two societies and cultures, between the first and second generation" (Rumbaut \& Ima, 1988, p. 2).

2 "These are students who are truly caught in the middle-between languages, cultures, and classrooms" (Oudenhoven, 2006, p. 243).

\section{References}

Antaki, C., \& Widdicombe, S. (Eds.). (1998). Identities in talk. London: Sage.

Baker, C. (2000). Locating culture in action: Membership categorization in texts and talk. In A. Lee \& C. Poynton (Eds.), Culture and text: Discourse and methodology in social research and cultural studies (pp. 99-113). Lanham, MD: Rowman \& Littlefield.

Bamberg, M., \& Georgakopoulou, A. (2008). Small stories as a new perspective in narrative and identity analysis. Text and Talk, 28(3), 377-396.

Benesch, S. (2007). What about the students? English language learners in postsecondary settings. In J. Cummins \& C. Davison (Eds.), International handbook of English language teaching (Vol. 2, pp. 655-667). New York: Springer.

Benesch, S. (2008). "Generation 1.5" and its discourses of partiality: A critical analysis. Journal of Language, Identity and Education, 7, 294-311.

Benesch, S. (2009). Interrogating in-between-ness: A postmodern perspective on immigrant students. In M. Roberge, M. Siegal, \& L. Harklau (Eds.), Generation 1.5 in college composition: Teaching writing to US educated learners of ESL (pp. 65-72). New York: Routledge.

Blackledge, A. (2005). Discourse and power in a multilingual world. Amsterdam: John Benjamins Bourdieu, P. (1991). Language and symbolic power. Cambridge, UK: Polity Press.

Bucholtz, M., \& Hall, K. (2004). Language and identity. In A. Duranti (Ed.), A companion to linguistic anthropology (pp. 369-394). Malden, MA: Blackwell.

Chomsky, N. (1965). Syntactic structures. The Hague: Mouton.

Fairclough, N. (1995). Critical discourse analysis: The critical study of language. New York: Longman. 
Foucault, M. (2003). Technologies of the self. In P. Rainbow \& N. Rose (Eds.), The essential Foucault: Selections from the essential works of Foucault, 1954-1984 (pp. 145-169). New York: New Press.

Garfinkel, H. (1967). Studies in ethnomethodology. Englewood Cliffs, NJ: Prentice Hall.

Goffman, E. (1955). On face-work: An analysis of ritual elements in social interaction. Journal for the Study of Interpersonal Processes, 18, 213-231.

Goffman, E. (1963). Stigma: Notes on the management of spoiled identity. Englewood Cliffs, NJ: Prentice Hall.

Goffman, E. (1983). The interaction order. American Sociological Review, 48(1), 1-17.

Goffman, E. (2001). Footing. In M. Wetherell, S. Taylor, \& S. J. Yates (Eds.), Discourse theory and practice: A reader (pp. 93-110). London: Sage Publications and the Open University.

Gubrium, J.F., \& Holstein, J.A. (Eds.). (2002). Handbook of interview research. Thousand Oaks, CA: Sage.

Gunderson, L. (2000). Voices of teen-aged diasporas. Journal of Adolescent and Adult Literacy, 43, 2-16.

Gunderson, L. (2007). English-only instruction and immigrant students in secondary schools: A critical examination. Mahwah, NJ: Erlbaum.

Han, H. (2009). Institutionalized inclusion: A case study on support for immigrants in English learning. TESOL Quarterly, 43, 643-668.

Han, H. (2011). "Love your China" and evangelize: Religion, nationalism, racism and immigrant settlement in Canada. Ethnography and Education, 6(1), 61-79.

Harklau, L. (2000). From the "good kids" to the "worst": Representations of English language learners across educational settings. TESOL Quarterly, 34, 35-67.

Harklau, L., Losey, K.M., \& Siegal, M. (Eds.). (1999). Generation 1.5 meets college composition: Issues in the teaching of writing to U.S.-educated learners of ESL. Mahwah, NJ: Erlbaum.

Heller, M., \& Martin-Jones, M. (2001). Introduction: Symbolic domination, education, and linguistic difference. In M. Heller \& M. Martin-Jones (Eds.), Voices of authority: Education and linguistic difference (pp. 1-28). Westport, CT: Ablex.

Heritage, J. (2004). Conversation analysis and institutional talk: Analyzing data. In D. Silverman (Ed.), Qualitative research: Theory, method and practice (2nd ed., pp. 222-245). Thousand Oaks, CA: Sage.

Heritage, J. (2005). Conversation analysis and institutional talk. In K.L. Fitch \& R.E. Sanders (Eds.), Handbook of language and social interaction (pp. 103-147). Mahway, NJ: Erlbaum.

Heritage, J., \& Greatbatch, D. (1991). On the institutional character of institutional talk: The case of news interviews. In D. Boden \& D.H. Zimmerman (Eds.), Talk and social structure (pp. 93-137). Berkeley, CA: University of California Press.

Hester, S. (1998). Describing "deviance" in school: Recognizably educational psychological problems. In C. Antaki \& S. Widdicombe (Eds.), Identities in talk (pp. 133-150). London: Sage.

Hester, S., \& Eglin, P. (Eds.). (1997). Culture in action: Studies in membership categorization analysis. Washington, DC: University Press of America.

Holstein, J. A., \& Gubrium, J. F. (2004). The active interview. In D. Silverman (Ed.), Qualitative research: Theory, method and practice (2nd ed., pp. 140-161). Thousand Oaks, CA: Sage.

Hopper, R., \& LeBaron, C. (1998). How gender creeps into talk. Research on Language and Social Interaction, 31(1), 59-74.

Hyman, H., Cobb, W., Feldman, J., Hart, C., \& Stember, C. (1975). Interviewing in social research. Chicago, IL: University of Chicago Press.

Jayyusi, L. (1984). Categorization and the moral order. London: Routledge.

Jefferson, G., Sacks, H., \& Schegloff, E. (1987). Notes on laughter in the pursuit of intimacy. In G. Button \& J.R.E. Lee (Eds.), Talk and social organization (pp. 152-205). Clevedon, UK: Multilingual Matters. 
Kim, J. (2008). Negotiating multiple investments in languages and identities: The language socialization of Generation 1.5 Korean-Canadian university students. Unpublished doctoral dissertation, University of British Columbia.. Available:

https://circle.ubc.ca/bitstream/handle/2429/2797/ubc_2009_spring_kim_jean.pdf?sequ ence $=1$

Kitzinger, C. (2000). Doing feminist conversation analysis. Feminism and Psychology, 10(2), 163-193.

Kitzinger, C. "Speaking as a heterosexual": (How) does sexuality matter for talk ininteraction? Research on Language and Social Interaction, 38(3), 221-265.

Lepper, G. (2000). Categories in text and talk: A practical introduction to categorization analysis. London: Sage.

Lipp, E. (2011, March). Bilingual Hispanic and South-East Asian students' challenges in a freshman history course. Paper presented at the Teachers of English to Speakers of Other Languages Annual Convention, New Orleans.

Marshall, S. (2010). Re-becoming ESL: Multilingual university students and a deficit identity. Language and Education, 24(1), 41-56.

Mehan, H. (2001). The construction of an LD student: A case study in the politics of representation. In M. Wetherell, S. Taylor, \& S.J. Yates (Eds.), Discourse theory and practice: A reader (pp. 345-363). London: Sage.

Oudenhoven, E.D. (2006). Caught in the middle: Generation 1.5 Latino students and English language learning at a community college. Unpublished doctoral dissertation. Available: ProQuest Dissertations \& Theses database (No. 3212980).

Pomerantz, A. (1986). Extreme case formulations: A way of legitimizing claims. Human Studies, 9(2-3), 219-229.

Potter, J. (1996). Representing reality: Discourse, rhetoric and social construction. London: Sage.

Pyke, K., \& Dang, T. (2003). "FOB" and "whitewashed": Identity and internalized racism among second generation Asian Americans. Qualitative Sociology, 26(2), 147-172.

Richards, K. (2006). "Being the teacher": Identity and classroom conversation. Applied Linguistics, 27(1), 51-77.

Roberge, M. (2009). A teacher's perspective on generation 1.5. In M. Roberge, M. Siegal, \& L. Harklau (Eds.), Generation 1.5 in college composition: Teaching academic writing to U.S.educated learners of ESL (pp. 3-24). New York: Routledge.

Roberge, M., Siegal, M., \& Harklau, L. (2009). Generation 1.5 in college composition: Teaching academic writing to U.S.-educated learners of ESL. New York: Routledge.

Rumbaut, R., \& Ima, K. (1988). The adaptation of Southeast Asian refugee youth: A comparative study. Available: ERIC database (ED299372).

Sacks, H. (1992). Lectures on conversation. Oxford, UK: Blackwell.

Sacks, H., Schegloff, E A., \& Jefferson, G. (1974). A simplest systematics for the organization of turn-taking for conversation. Language, 50, 696-735.

Schegloff, E.A. (2007). Sequence organization in interaction: A primer in conversation analysis (Vol. 1). Cambridge, UK: Cambridge University Press.

Schiffrin, D. (1987). Discourse markers. Cambridge, UK: Cambridge University Press.

Silverman, D. (1998). Harvey Sacks: Social science and conversation analysis. Cambridge, UK: Polity Press.

Stokoe, E.H. (2010). "I'm not gonna hit a lady": Conversation analysis, membership categorization and men's denials of violence towards women. Discourse and Society, 21(1), 59-82.

Stokoe, E.H., \& Smithson, J. (2001). Making gender relevant: Conversation analysis and gender categories in interaction. Discourse and Society, 12(2), 217-244.

Talmy, S. (2005). Lifers and FOBs, rocks and resistance: Generation 1.5, identity, and the cultural productions of ESL in a high school. Unpublished doctoral dissertation, University of Hawai'i at Manoa. 
Talmy, S. (2009). Resisting ESL: Categories and sequence in a critically "motivated" analysis of classroom interaction. In H.T. Nguyen \& G. Kasper (Eds.), Talk-in-interaction: Multilingual perspectives (pp. 181-213). Honolulu, HI: National Foreign Language Resource Center, University of Hawai'i at Manoa.

Talmy, S. (2010). Achieving distinction through Mock ESL: A critical pragmatics analysis of classroom talk in a high school. In G. Kasper, H.T. Nguyen, D. Yoshimi, \& J. Yoshioka (Eds.), Pragmatics and language learning 12 (pp. 215-254). Honolulu, HI: National Foreign Language Resource Center, University of Hawai'i at Manoa.

ten Have, P. (2007). Doing conversation analysis: A practical guide (2nd ed.). London: Sage.

Threadgold, T. (2001). Making theories for different worlds: Making critical differences. In P. Freebody, S. Muspratt, \& B. Dwyer (Eds.), Difference, silence, and textual practice (pp. 209242). Cresskill, NJ: Hampton Press.

Van Dijk, T. (2001). Multidisciplinary CDA: A plea for diversity. In R. Wodak \& M. Meyer (Eds.), Methods of critical discourse analysis (pp. 95-120). London: Sage.

Wilkinson, S., \& Kitzinger, C. (2008). Using conversation analysis in feminist and critical research. Social and Personality Psychology Compass, 2, 555-573.

Wooffitt, R. (2001). Researching psychic practitioners: Conversation analysis. In M. Wetherell, S. Taylor, \& S.J. Yates (Eds.), Discourse as data: A guide for analysis (pp. 49-92). London: Sage Publications and the Open University Press.

Zimmerman, D.H. (1998). Discourse identities and social identities: Identity, context and interaction. In C. Antaki \& S. Widdicombe (Eds.), Identities in talk (pp. 87-106). London: Sage. 


\section{Appendix A: Transcription Symbols}

(.)

.hh

pt

hh

:

?

hehheh Indicates laughter.

wo(h)rd (h) denotes laughter within words.

under Underlined fragments indicate speaker emphasis.

$\uparrow$ word Arrows indicate the onset of a rising or falling intonational shift.

$\downarrow$ word

run $=$

$=$ on

CAPITALS Capital letters indicate speech noticeably louder than that surrounding it.

$\circ \circ$ Degree signs indicate speech spoken noticeably more quietly than the surrounding talk.

$>$ fast $<\quad$ More-than and less-than signs indicate that the talk they encompass $<$ slow $>\quad$ was produced noticeably quicker than the surrounding talk.

[]
A double left-hand bracket indicates that speakers start a turn simultaneously. 